\title{
Structural and Functional Composition \\ of Humic Acids Isolated from Soils of Natural \\ and Urbanized Territories \\ of the European Far North and the Arctic
}

\author{
Tatiana A. Korelskaya*, \\ Natalia S. Prilutskaya and Lyudmila F. Popova \\ Northern state medical University, \\ Arkhangelsk, Russian Federation \\ Northern (Arctic) Federal University \\ named after M. V. Lomonosov, \\ Arkhangelsk, Russian Federation
}

Received 27.05.2021, received in revised form 16.11.2021, accepted 13.01.2022

\begin{abstract}
The structural and functional composition of humic acids in natural and urbanized areas of the European Far North and the Arctic has been studied using modern physical and chemical research methods. It is shown that the content of fulvic acids for most of the studied soils is higher than humic acids; in soils, the process of humus formation is humate (replantozem, pelozem and humus-peat soil), humate-fulvate (turf soil, culturozem and urbanozem) and fulvate type (gleezem and lithozem); macromolecules of humic acids and himatomelanic acids of the studied soils are predominantly aliphatic in nature, with a high proportion of aromatic fragments, and FA have an aromatic structure. In addition, humus acids of natural soils located in more Northern regions are characterized by a high content of oxygen-containing functional groups compared to humus acids preparations of natural soils located to the South (turf and peat).
\end{abstract}

Keywords: structural and functional composition of humic acids, humic acids, fulvic acids, himatomelanic acids, IR-spectroscopy, UV/visible spectroscopy.

Citation: Korelskaya, T. A., Prilutskaya, N. S., Popova, L.F. Structural and functional composition of humic acids isolated from soils of natural and urbanized territories of the European Far North and the Arctic. J. Sib. Fed. Univ. Chem., 2022, 15(1), 14-21. DOI: 10.17516/1998-2836-0267

(c) Siberian Federal University. All rights reserved

This work is licensed under a Creative Commons Attribution-NonCommercial 4.0 International License (CC BY-NC 4.0).

* Corresponding author E-mail address: takorelskaya@yandex.ru 


\title{
Структурно-функциональный состав гумусовых кислот, выделенных из почв природных \\ и урбанизированных территорий \\ европейской части Крайнего Севера и Арктики
}

\author{
Т. А. Корельская, Н. С. Прилуцкая, Л. Ф. Попова \\ Северный государственный медииинский университет \\ Российская Федераиия, Архангельск \\ Северный (Арктический) федеральный университет \\ имени М.В. Ломоносова \\ Российская Федерачия, Архангельск
}

\begin{abstract}
Аннотация. Исследован структурно-функциональный состав гумусовых кислот природных и урбанизированных территорий европейской части Крайнего Севера и Арктики с помощью современных физико-химических методов. Показано, что содержание фульвокислот для большинства изучаемых почв выше, чем гуминовых; в почвах процесс гумусообразования идет по гуматному (реплантозем, пелозем и перегнойно-торфяная почва), гуматно-фульватному (дерновая почва, культурозем и урбанозем) и фульватному типу (глеезем и литозем); макромолекулы гуминовых и гиматомелановых кислот рассмотренных почв имеют преимущественно алифатическую природу с высокой долей ароматических фрагментов, а фульфовых - ароматическую структуру. Кроме того, гумусовые кислоты природных почв, расположенных в более северных регионах, отличаются большим содержанием кислородосодержащих функциональных групп по сравнению с аналогичными препаратами природных почв, расположенных южнее (дерновая почва и торф).
\end{abstract}

Ключевые слова: структурно-функциональный состав гумусовых кислот, гуминовые кислоты, фульвокислоты, гиматомелановые кислоты, элементный анализ, ИК-спектроскопия, УФ/Видимая спектроскопия.

Цитирование: Корельская, Т. А. Структурно-функциональный состав гумусовых кислот, выделенных из почв природных и урбанизированных территорий европейской части Крайнего Севера и Арктики / Т. А. Корельская, Н.С. Прилуцкая, Л. Ф. Попова // Журн. Сиб. федер. унта. Химия, 2022, 15(1). С. 14-21. DOI: 10.17516/1998-2836-0267

\section{Introduction}

Currently, many studies are being conducted to study the structural and functional composition of humus acids (HMFA) in soils of different regions using modern physical and chemical methods $[1,2,3]$.

Research on the soils of the Euro-Arctic region, in particular their organic component, is just beginning. For these soils is known only to basic characteristics such as: soil genesis, soil structure, soil profile, humus content [4] and heavy metals (HM) in them [5], data on their ecological state [5]. 
The aim of this work is to study the structural and functional composition of HMFA in natural and urbanized areas of the European Far North and the Arctic using modern physical and chemical methods.

\section{Object of research}

The object of the study was selected HMFA preparations isolated from the soils of natural and urbanized territories of the European Far North and the European Arctic. Urban soils are soil samples from the residential landscape of the city of Arkhangelsk of the following types: urbanozem, replantozem and culturozem [5]. To study the humus state of natural soils, we selected a natural turf low-power light-loam soil formed on a dry meadow near the village of Babonegovo in the Primorsky district of the Arkhangelsk region, natural and anthropogenic soils - organogenic soils (riding peat, selected in the Primorsky district of the Arkhangelsk region) [5] and soils selected during the complex scientific and educational expedition «Arctic floating University-2013»: pelozem gleevaty light loam on a mediumclay moraine (Kanin Peninsula on Cape Kanin nos), humus-peat oligotrophic soil (Kolguev island and Bugrino village), typical carbonate-free medium-clay loam (svaygach), gray-humus illuvial-ferruginous sand lithosem (Franz Josef land archipelago on Hayes island) [6, 7, 8].

\section{Research methods and techniques}

The isolation of HMFA preparations from soil samples was carried out by the method of M. M. Kononova and N.P. Belchikova [10]. The method is based on the extraction of a mixture of acids from the soil with an alkaline solution of sodium pyrophosphate $(\mathrm{pH} 13)$, followed by the precipitation of humic (HA) and himatomelanic acids (HMA) $1 \mathrm{~N} \mathrm{H}_{2} \mathrm{SO}_{4}$ and their separation from fulvic acids (FA) with additional extraction of FA by adsorption chromatography using activated carbon as a sorbent.

Features of the structure of HMFA were studied by modern physical and chemical methods, such as:

- elemental analysis (performed using the EA-3000 elemental CHNS analyzer);

- UV / visible spectroscopy (UV recording/Visible spectra were performed on a UV mini-1240 spectrophotometer manufactured by Shimadzu)

- IR spectroscopy (recording of IR spectra was performed under the same conditions by the method of external total internal reflection on the Vertex 70v IR Fourier spectrometer with pre-pressing of samples into tablets with potassium bromide in the ratio 1/200) in the frequency range from 500 to $4000 \mathrm{~cm}$ -

\section{Results and discussion}

Based on experimental data for determining the group composition (Fig. 1), it was found that the content of HMFA, including HA, in the soils of urbanized territories is higher than in natural soils (except for turf and peat), which is associated with the geographical location of soils in the Arctic and subarctic climate zones.

Most of the studied soil types are characterized by a higher content of FA compared to the content of HA. However, the content HA: FA points to the process of humification mainly on humate-fulvate type most soils in urbanized areas (with the exception of replantozem (humate type)), and in natural soils found fulvate type of humification (e. g. gleezem and lithozem).

Analysis of IR spectra of [11, 12] humic acids of natural and urbanized soils (examples of IR spectra are shown in Fig. 2) was carried out according to a set of specific absorption bands, on the basis of which the qualitative composition of the samples, the structure of macromolecules, the 


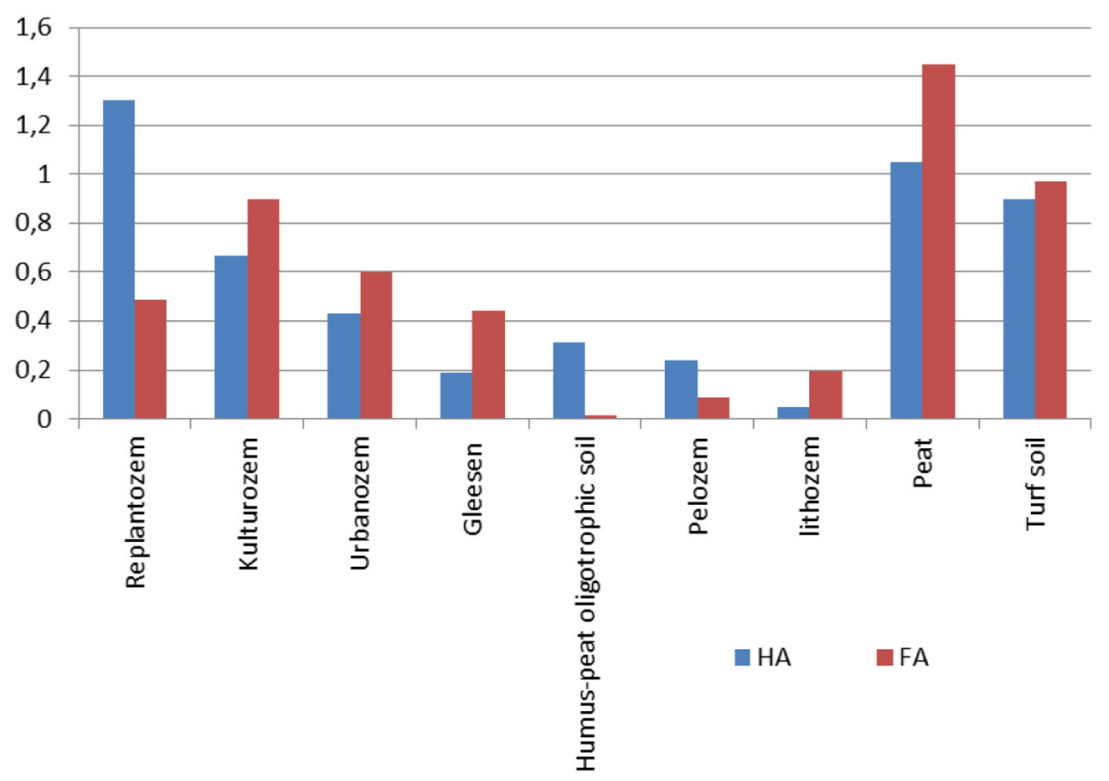

Fig. 1 content of HA and FA in the studied soils, $\%$

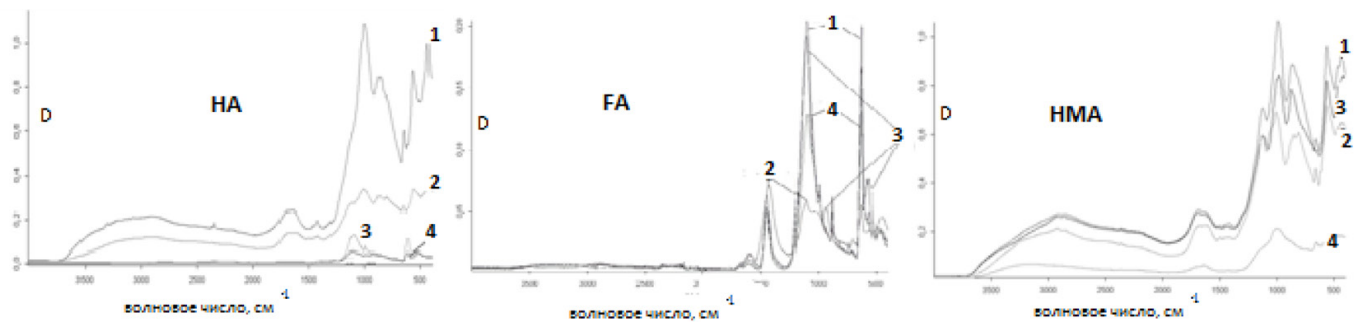

1 - gleezem; 2 - humus-peat soil; 3 - pelozem; 4 - lithozem

Fig. 2 IR spectra of HMFA of the studied soils (on the example of natural soils)

types of bonds and atomic groupings were judged. All the studied HMFA spectra are characterized by intense absorption in the region of 3400 and $3200 \mathrm{~cm}^{-1}$, which, according to many researchers $[13,14,21]$, is due to the presence of- $\mathrm{OH}$ and- $\mathrm{C}=\mathrm{N}-\mathrm{H}$ groups and intermolecular hydrogen bonds. Methylene $(-\mathrm{CH} 2)$, carboxyl $(-\mathrm{COOH})$, alcohol $(-\mathrm{OH})$, thiocarbonyl $(-\mathrm{C}=\mathrm{S})$, amine $(-\mathrm{NH} 2)$ and amide $(-\mathrm{CONH} 2)$ groups were identified in the molecules of all acids, due to which the studied HMFA are able to bind HM in the form of complex compounds. Similar data were obtained by other researchers $[15,16,18]$.

The comparison of the HMFA spectra was carried out on the basis of an assessment of the degree of absorption by the baseline method, which was carried out at the base of the absorption band [17]. As standard bands, the following were taken: 2920, 2930 and $2934 \mathrm{~cm}^{-1}$, characterizing the valence vibrations of $\mathrm{C}-\mathrm{H}$ bonds in aliphatic fragments of HMFA. The relative content of functional groups was estimated by calculating the optical density according to the Booger-Behr formula. Based on the IR spectra, the ratio of the optical densities of the absorption bands of aliphatic substituents at $2920 \mathrm{~cm}^{-1}$ to the optical densities of the absorption bands of aromatic poly-conjugated systems at 
$1610 \mathrm{~cm}^{-1}\left(\mathrm{D}_{2920} / \mathrm{D}_{1610}\right)$ was calculated (Table 1$)$. The lower this ratio, the more aromatic fragments in the structure of HA molecules [15].

Analysis of the IR spectra of HMFA showed that the aliphatic component mainly prevails in the HMFA molecules of urbanized soils, while the aromatic component prevails in the HMFA molecules of natural soils $[7,8]$.

A qualitative analysis of the UV / visible spectra of the studied humic acids, some examples of which are shown in Fig. 3, showed their similar shape. The electronic spectra have the form of gentle curves with an absorption maximum in the range of 213-215 $\mathrm{nm}$ (due to the whole set of organic substances) and a characteristic shoulder in the region of $280 \mathrm{~nm}$ (due to the presence of phenolic and carboxyl groups in the molecules), which corresponds to the known data, according to which the main chain of HA molecules is constructed from fragments of phenyl carboxylic acids [18]. In the rest of the range of the UV and visible regions of the spectrum, there are no clearly defined absorption maxima, which indicates their overlap due to the complex structure of HFMA molecules. Most authors associate the nature of the electronic absorption spectra and the color of humic substances with a system of conjugated double bonds [19].

Therefore, another spectroscopic characteristic of HFMA is the color coefficient (E450/E650), which characterizes the steepness of the spectrum drop and the nature of their color, this ratio does not depend

Table 1. Indicators $C_{\text {alk }} 2920 / C=C 1610$ of the HMFA of the studied soils

\begin{tabular}{|l|c|c|c|}
\hline \multicolumn{1}{|c|}{ Soil type } & HA & FA & HMA \\
\hline Replantozem & 0,25 & 1,70 & 0,50 \\
\hline Kulturozem & 0,81 & 3,52 & 1,70 \\
\hline Urbanozem & 1,10 & 0,14 & 1,51 \\
\hline Gleesen typical carbonate-free medium loamy & 0,36 & 2,73 & 0,37 \\
\hline Humus-peat oligotrophic soil & 0,36 & 1,42 & 0,30 \\
\hline Pelozem gleyevaty light loamy on a medium-loamy morainee & 1,64 & 0,71 & 0,28 \\
\hline Gray-humus illuvial-ferruginous sandy lithozem & 1,00 & 2,26 & 0,53 \\
\hline Peat & 1,3 & 1,29 & 0,39 \\
\hline Turf soil & 0,19 & 0,04 & 0,57 \\
\hline
\end{tabular}
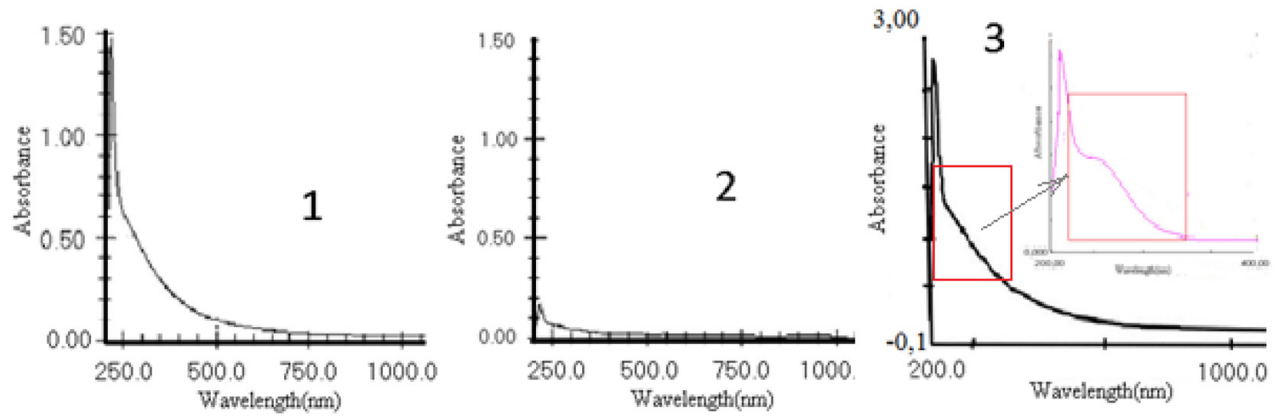

1 - humus-peat soil; 2 -gleezem; 3 - turf soil

Fig. 3 UV / visible HFA spectra of the studied soils on the example of HA 
Table 2. Indicators E450/E650 of the HFMA of the studied soils

\begin{tabular}{|l|c|c|c|}
\hline \multicolumn{1}{|c|}{ Soil type } & HA & FA & HMA \\
\hline Kulturozem & 3,17 & 3,60 & 3,00 \\
\hline Replantozem & 4,42 & 2,00 & 3,40 \\
\hline Urbanozem & 3,31 & 1,60 & 2,52 \\
\hline Gleesen typical carbonate-free medium loamy & 3,01 & 2,12 & 3,00 \\
\hline Humus-peat oligotrophic soil & 2,6 & 1,54 & 2,40 \\
\hline Pelozem gleyevaty light loamy on a medium-loamy morainee & 4,5 & 1,12 & 2,38 \\
\hline Gray-humus illuvial-ferruginous sandy lithozem & 2,57 & 1,75 & 2,38 \\
\hline Turf soil & 3,36 & 3,02 & 1,80 \\
\hline Peat & 3,85 & 3,50 & 4,00 \\
\hline
\end{tabular}

on the concentration, but it depends on the particle size and molecular weight. According to the literature data, it is known [20] that the color coefficient can characterize the ratio of the aliphatic component of the molecule to the aromatic one. The lower the E450/E650 ratio, the higher the degree of aromaticity.

For HFMA of all natural soils, as well as urbanozems and replantozems, a decrease in the value of the color coefficient in the series: HA $>$ HMA $>$ FA is characteristic (Table 2). This indicates a weak degree of condensation of the aromatic core of HA and HMA.

The higher chromaticity coefficients of HA and HMA compared to FA in most of the studied samples may be related to:

- with the presence of a large number of separate conjugation chains in large molecules of HMA and HA, which leads to the imposition of color and, consequently, the appearance of a dark color of acids;

- with the participation in the conjugation chain of such chromophore groups as $-\mathrm{CH}=\mathrm{CH}$-, $-\mathrm{CH}=\mathrm{N}-,-\mathrm{N}=\mathrm{N}-,=\mathrm{C}=\mathrm{O}$, etc., and auxochromes $-\mathrm{OH},-\mathrm{NH}_{2}$. Accordingly, in the molecules of $\mathrm{HA}$ and HMA, the conjugation chains are less long, and the aromatic fragments, chromophore and auxochromic groups are separated by aliphatic fragments.

All HFMA of peat and culturosem have a fairly low level of aromaticity and condensation. Among the studied HMA preparations, the greatest condensation of the aromatic core is noted for the HMA of turf soil.

In general, samples of soils HFMA of urbanized territories, natural turf soil and peat have a more expressed steepness of the spectral curves, which indicates the presence of a well-developed peripheral aliphatic component in their molecules. This is confirmed by both elemental analysis and IR spectroscopy data. HFMA preparations of other natural soils have a more gentle spectral curve, which indicates the development of aromatic structures in the nuclear part of the molecules.

\section{Conclusions}

The study of humic acids in natural and urbanized areas of the European Far North and the Arctic showed that:

1) the total content of HMFA, including HA, in the soils of urbanized territories is higher than in natural soils (except for turf and peat) and is associated with the location of the latter in the Arctic and subarctic climate zones; 
2) in the soils of urbanized areas, the process of humification is on humate (replantozem) and humate-fulvate (culturozem and urbanozem) type, in natural soils in addition to humate (pelozem and humus-peat soil) and humate-fulvate (turf soil) types can be found falvate type of humification (gleezem and lithozem).

3) macromolecules of HMFA of soils of urbanized territories and HA and HMA of natural soils have an aliphatic nature with a high proportion of aromatic fragments, and FA of natural soils-mainly aromatic;

4) thiocarbonyl $(-\mathrm{C}=\mathrm{S})$, amine $\left(-\mathrm{NH}_{2}\right)$ and amide $\left(-\mathrm{CONH}_{2}\right)$ groups were identified in the molecules of all the studied acids;

5) oxygen-containing functional groups make a great contribution to the structure of the HMFA molecules of natural soils and soils of urbanized territories, and their total content in the HMFA of urbanized territories is higher than in the HMFA of natural soils.

\section{References}

1. Lobanov, V.G., Aleksandrova, A.V., Shuray, K.N., Avdeev, A.S., Rashid, I. D. Structural and Functional Characteristics of the Humic Acid Soils of the Krasnodar Region. Polythematic Online Scientific J. of Kuban State Agrarian Univ. 2015. Vol. 109. P. 1016-1025. Available at: http://www. ej.kubagro.ru/2015/05/pdf/71.pdf (In Russ.)

2. Lodygin, E.D., Beznosikov, V.A., Chukov, S. N. Structural and Functional Parameters of Humic Substances of Podzolic and Swamp-Podzolic Soils. Saint Petersburg, 2007. 145 p. (In Russ.)

3. Nesterova, O.V., Semal', V. A. Characterization of Humic Acids of Brown Soils of the South of Sikhote-Alin According to the Elemental Analysis and Infrared Spectroscopy (the Case of the Ussuri Reserve). The Bulletin of KrasGAU. 2009. Vol. 10. P. 29-35 (In Russ.)

4. Lyubova, S.V., Lyubova, N. V. The Soils of the Arctic and Some of Their Properties. Ecological Problems of the Arctic and Northern Territories. Arkhangelsk, 2016. P. 254-257 (In Russ.)

5. Vishnevaya, Yu.S., Popova, L.F. Assessment of the Environmental Status and Degree of Pollution of Arctic Soils by Heavy Metals. Bulletin of the Moscow State Regional Univ. Ser.: Natural Science. 2016. Vol. 2. P. 96-104 (In Russ.)

6. Resolution of the Council of Ministers of the USSR of 03.01.1983 N12 (ed. of 27.02.2018) «On amendments and additions to the List of districts of the Far North and localities equated to the far North regions, approved by The resolution of the Council of Ministers of the USSR of November 10, 1967. \# 1029 (In Russ.)

7. Korelskaya, T.A, Rumyantseva, T.I. The Structure of Humic Acids as a Function of the Performance of Ecoprotective Role for Heavy Metals. J. of Sib. Fed. Univ. Chem. 2014. Vol. 7(1). P. 139-150 (In Russ.)

8. Prilutskaya, N. S., Korel'skaya, T. A., Popova, L. F., Leont'eva, V. A. The study of the structural and functional composition of soil humus acids of the Euro-Arctic region by infrared spectroscopy. Bulletin of NArFU. Ser.: Natural Sciences. 2016. Vol. 4. P. 26-35 (In Russ.)

9. Prilutskaya, N. S., Korel'skaya, T. A., Popova, L.F. The study of the structural and functional composition of soil humus acids of the Euro-Arctic region by UV/visible spectroscopy. Russian J. Of Chem. And Chemical Technology. 2018. Vol. 61(2). P. 97-103 (In Russ.)

10. Kononova, M.M., Belchikova, N. P. Rapid Determining Methods of the Humus Composition. Eurasian Soil Science. 1961. Vol. 10. P. 75-87 (In Russ.) 
11. Pretsch, E., Buhlmann, P., Affolter, C. Structure Determination of Organic Compounds. Tables of Spectral Data. Berlin; Heidelberg; New York; Barcelona; Hong Kong; London; Milan; Paris; Singapore; Tokyo, 2000. 473 p.

12. Silverstein, R.M., Webster, F.X., Kiemle, D. J. Spectrometric Identification of Organic Compounds. US, 2005. $512 \mathrm{p}$.

13. Krivopalova, M. A. Avvakumova, N.P., Zhdanova, A. V. Humic acids of peloids as promising adsorption agents. National Association of Scientists. 2015. № 9-4(14). P. 56-57.

14. Chimitdorzhieva, G. D. Organic substance of cold soils. Ulan-Ude. Buryat Scientific Center of the SB RAS, 2016. 388 p.

15. Orlov, D. S., Rozanova, O. N., Matyukhina, S. G. Infrared absorption spectra of humic acids. Soil science. 1962. Vol. 1. P. 17-25.

16. Motuzova, G.V., Derham, H.M., Stepanov, A. A. Comparative characteristics of humic acids of arable soils of taiga, steppe and semi-desert zones. Soil science. 2012. Vol. 11. P. 1171.

17. Sartakov, M.P., Chumak, V. A. Infrared absorption spectra of humic acids of alluvial soils of the Ob-Irtysh floodplain. Bulletin of KrasGAU. 2013. Vol. 8(83). P. 53-56.

18. Gostischeva, M. V., Inisheva, L. I., Fedko, I. V. Research of chemical and biological properties of humic acids of peat of various origin. Peat in solving problems of energy, agriculture and ecology. Materials of the international conference. May 29. June 2. Minsk, 2006. P. 181-184.

19. Aristilde, L., Sposito, G. Complexes of the antimicrobial ciprofloxacin with soil, peat, and aquatic humic substances. Environmental toxicology and chem. 2013. Vol. 32(7). P. 1467--1478.

20. Lodygin, E. D., Beznosikov, V. A., Vasilevich, R. S. Structural composition of humus substances of tundra soils. Humic substances in the biosphere. Materials of the VI Russian Scientific Conference with international participation. Syktyvkar, 2014. P. 60--63.

21. Aeschbacher, M., Graf, C., Schwarzenbach, R.P., Sander, M. Antioxidant properties of humic substances. Environ. Sci. Technol. 2012. Vol. 46. P. 4916-4925.

22. Shang, E.X.; Li, Y.; Niu, J.F.; Zhou, Y.J.; Wang, T.Y.; Crittenden, J.C. Relative importance of humic and fulvic acid on ROS generation, dissolution, and toxicity of sulfide nanoparticles. Water Res. 2017. Vol. 124. P. 595-604. 